ISSN: Print 2075 - 146X, Online 2616-6623. Витоки педагогічної майстерності. 2020. Випуск 25

Tarasenkova, N. A. (2002b). Pryiom vizualizatsii pomylok yak sposib operatyvnoho korektuvannia znan uchniv pid chas usnoho opytuvannia [Reception of visualization of errors as a way of operative correction of knowledge of pupils during oral interrogation]. Matematyka $v$ shkoli [Mathematics at school], 3, 32-35 [in Ukrainian].

CHERKASKA L., MOSKALENKO O., KOVALENKO 0.

Poltava V. G. Korolenko national pedagogical University, Ukraine

\title{
MISTAKE PREVENTION AS A COMPONENT OF THE CORRECTION OF STUDENT LEARNING OUTCOMES IN THE SYSTEM OF MATHEMATICS LESSONS
}

Correcting student learning outcomes is an integral part of the educational process. The need for correction arises in case of discrepancy between the planned and actually obtained learning outcomes. Correction acquires special significance during the teaching of mathematics, because gaps in the subject preparation of students that have not been identified and eliminated in time will not allow them to successfully acquire new knowledge and skills in the future. After all, mathematics as a science and as a subject is characterized by very close inter-conceptual, intra-thematic and intra-subject connections. Therefore, insufficient mastery of one topic by students will lead to a negative tendency to master others that are meaningfully related to it.

The analysis of a wide source base, the conducted pedagogical experiment allowed to be defined with definition and structure of procedure of correction of results of training of pupils. The selection of two components of correction prevention of students' mistakes and elimination of mistakes (situational and systemic) - necessitate the creation of appropriate methodological and didactic support for their practical implementation in the educational process. This article considers the features of the organization of preventive work to prevent mathematical errors of schoolchildren, identifies the main types, forms, methods, means of correction inherent in this component.

Based on the classification of lessons by the main didactic purpose, didactic models of the procedure of correction of knowledge and skills of students in mathematics in each of the six types of lessons were created. Attention was focused on the feasibility and prospects of effective work to prevent mistakes, the allocation of methods and means of such work in the classroom in accordance with the goal.

The content and organizational content of the considered models of correction will allow to realize in practice the systematic approach to use of procedure of correction in the course of training of mathematics for increase of its efficiency.

Key words: educational process, correction of learning outcomes, prevention of mistakes, control of knowledge and skills of students, mathematics lessons

Стаття надійшла до редакції 29.07.2020 p.

УДК 378.091.212-044.332

DOI: https://doi.org/10.33989/2075-146x.2020.25.223338

\section{СВІТЛАНА ШАРА}

ORCID: 0000-0003-4309-5794

Вищий навчальний заклад Укоопспілки «Полтавський університет економіки і торгівлі»

\section{УМОВИ АДАПТАЦІЇ СТУДЕНТІВ МОЛОДШИХ КУРСІВ ДО ОСВІТНЬОГО СЕРЕДОВИЩА ЗВО В ПРОЦЕСІ ФАХОВОЇ ПІДГОТОВКИ}

Розглянуто поняття «адаптація» та наближені до нього поняття та концепти. 3'ясовано сутність концепту адаптація студентів молодших курсів до освітнього середовища вищого навчального закладу в процесі фахової підготовки. Визначено й обгрунтовано організаційнопедагогічні умови адаптації студентів першого й другого курсів до освітнього середовища вищого навчального закладу у процесі фахової підготовки (середовищні, стимулювально-діяльнісні, превентивні).

Ключові слова: адаптація, студенти, освітнє середовище, фахова підготовка, педагогічні умови адаптації студентів до освітнього середовища закладу вищої освіти в процесі фахової підготовки

Постановка проблеми. Процес євроінтеграції детермінує прискорення соціально-економічного поступу України. Це, як зазначено в Національній доктрині розвитку освіти, зумовлює необхідність удосконалити підготовку майбутніх фахівців у системі вищої освіти, зумовлюючи тим самим підвищення освітнього і культурного рівня українського суспільства в цілому.

У цьому контексті стає актуальним завдання перетворення соціального складника освітнього середовища закладу вищої освіти на високоорганізовану спільноту з прогресивними системами цінностей, продуктивною діяльністю, здатну забезпечити умови становлення особистості, яка компетентно вирішує як власні професійні проблеми, так і відзначається активною громадянською позицією. 
Проте практика свідчить, що рівень підготовки студентів, майбутніх кваліфікованих фахівців тієї чи іншої галузі, істотно залежить від їхньої успішної адаптації до освітнього середовища закладу вищої освіти та його впливу на процес їхньої фахової підготовки.

Це особливо стосується студентів першого й другого курсу закладів вищої освіти, оскільки саме тут закладаються основи ставлення до себе як професіонала.

Отже, процес підготовки майбутніх фахівців у педагогічному ЗВО за своєю суттю $є$ адаптивним, бо саме в його ході відбувається поєднання на практиці вимог професії до особистості студента та його можливостей. Від цього залежить зміцнення професійної мотивації, подальший професійний та особистісний розвиток майбутнього педагога.

Те ж саме, хоч і дещо в іншому контексті, можна сказати й про не педагогічні ЗВО. Адже вища освіта відрізняється від інших рівнів здійснення професійної підготовки ще й тим, що іiї здобувач формується як потенційний управлінець, фахівець, який організує роботу інших працівників, спрямовану на виконання спільних систематизованих завдань. У ЗВО відбувається всебічний культурний і комунікативний розвиток студента, формуються поведінкові навички, характерні для інтелігентної людини, а також мотиви і вміння здійснення особистісно-професійного саморозвитку, що повинні проявлятися вже в період навчання. Тож певною мірою проблема адаптації студентів молодших курсів є спільною для всіх закладів вищої освіти незалежно від їхнього профілю.

Проте через недостатне використання в сучасних ЗВО методик конструктивного подолання студентами численних труднощів адаптації до освітнього середовища ЗВО в процесі фахової підготовки успішне досягнення такого результату спостерігаємо не завжди, хоча запит на неї об'єктивно має бути високим.

Аналіз досліджень і публікацій. Порушена проблема закономірно стала предметом багатьох психологопедагогічних розвідок, де досліджено адаптацію студентів до умов навчання й життєдіяльності в педагогічних та непедагогічних вищих навчальних закладах (Т. Алексеєва, Ю. Бохонкова, М. Горліченко, Л. Григоренко, С. Гура, В. Лагерєв, Г. Левківська, С. Селівестров та ін.).

Основи вивчення порушеного питання на актуальних засадах закладено у працях сучасних науковців, які розглядали проблему адаптації особистості в різноманітних аспектах: у соціокультурному та філософському (В. Верещагін, Ю. Ган, С. Кінелєв, Г. Царегородцев, Л. Шпак та ін.); психологічному (Б. Ананьєв, Г. Балл, О. Бодальов, О. Киричук); соціологічному (О. Алексєєва, Є. Вітенберг, I. Калайков); педагогічному (Л. Закутська,О. Плотникова. С. Савченко, С. Селіверстов, Г. Чуткіна); соціально-педагогічному (Н. Жукова, С. Подмазан, Н. Сас, І. Цимбал).

Стосовно різних профілів ЗВО зазначену проблему розглядали в своїх наукових розвідках О. Галус, С. Ізбаш, Т. Каткова, Д. Лопарєва, Б. Німаєв, Д. Новіков, В. Павлушенко, Л. Петльована, Р. Пріма, В. Цибулько та інші вчені. Однак проблема адаптації студентів першого й другого курсів до освітнього середовища вищого навчального закладу в процесі фахової підготовки не була предметом окремого дослідження, а отже є актуальною.

У цьому плані доречно зазначити, що освітнє середовище закладу вищої освіти розглядається вченими також у різних аспектах. Зокрема, адаптацію студентів в умовах оптимізації освітнього середовища досліджували Г. Горська, Т. Браун. Освітнє середовище як засіб розвитку творчої особистості студента стала предметом уваги дослідників В. Мастерова, С. Пимонова, І. Подольської (Левківська, Сорочинська \& Штифорук, 2001). Але його вплив на адаптацію студентів у процесі фахової підготовки залишається недостатньо вивченим. Це підтверджується й низкою суперечностей між:

- об’єктивною потребою суспільства у формуванні освіченої, творчої особистості 3 високим рівнем адаптованості до професійної діяльності та браком системних досліджень адаптації студентів до освітнього середовища вищого навчального закладу та його вплив на процес фахової підготовки;

- необхідністю створення педагогічних умов адаптації студентів до освітнього середовища 3ВО у процесі фахової підготовки та відсутністю достатнього науково-теоретичного обгрунтування й методичного забезпечення цього процесу.

Мета статті полягає в теоретичному обгрунтуванні педагогічних умов адаптації студентів першого й другого курсів до освітнього середовища вищого навчального закладу в процесі фахової підготовки.

Сформульована мета конкретизується в наступних завданнях:

1. Проаналізувати наукові здобутки вчених із зазначеної проблеми.

2. 3’ясувати змістову сутність поняття «адаптація» та наближені до нього концепти: «адаптація студентів молодших (першого й другого) курсів до освітнього середовища вищого навчального закладу в процесі фахової підготовки»; «професійна адаптація»; «соціальна адаптація»; «навчальна адаптація».

3. Визначити й теоретично обгрунтувати педагогічні умови адаптації студентів першого й другого курсів до освітнього середовища закладу вищої освіти в процесі фахової підготовки.

Виклад основного матеріалу. Освітнє середовище вищого навчального закладу, на думку дослідників (Братко, 2015 , с. 14-15), являє собою «багатосуб'єктне та багатопредметне системне утворення, що має можливості цілеспрямовано впливати на професійно-особистісний розвиток майбутнього фахівця, забезпечуючи його готовність до професійної діяльності та/або продовження навчання, успішного виконання соціальних ролей та самореалізації у процесі життєдіяльності». Тож адаптація до нього є внутрішньо різноплановим явищем, що не завжди має швидкий та успішний перебіг.

Що ж характерне для цього процесу? Враховуючи думку вчених стосовно того, що будь-яке наукове поняття знаходить своє місце у системі науки в результаті тривалого і складного процесу категоризації, ми зробили спробу проаналізувати, схарактеризувати та уточнити сутність базових понять нашого дослідження в системі психологопедагогічного знання. Насамперед, нами виділено поняття «адаптація». Такий підхід умотивовується тим, що, поперше, семантичне поле поняття «адаптація» останнім часом розширилося, характеризується полісемічністю, тобто 
включає в себе кілька значень, які залежно від контексту (ситуації), можуть торкатися переважно як особистісних, так і соціальних аспектів буття.

На цій проблемі наголошують, зокрема, В. Ячменьова та 3. Османова, зауважуючи, що «саме завдяки загальнонауковому статусу поняття «адаптація» та «адаптивність» дотепер не мають чіткого, усіма визнаного, визначення, як і усі поняття, які використовуються більш ніж в одній галузі знань» (Ячменьова \& Османова, 2010, с. 347).

Вивчення сутності поняття «адаптація» в психології, соціології, педагогіці уможливило твердження про те, що цей феномен пов'язаний не тільки з процесами пристосування людини до нових умов діяльності, а й із особистісним і професійним становленням індивіда.

Соціальна адаптація - це процес активного пристосування індивіда (групи індивідів) до соціального середовища, який проявляється у забезпеченні умов, що сприяють реалізації потреб, інтересів, життєвої мети цього індивіда. Соціальна адаптація включає пристосування до умов і характеру праці (навчання), а також до характеру міжособистісних стосунків, екологічного, культурного, освітнього середовища, проведення дозвілля, побуту.

Соціальна адаптація студентів першого й другого курсів до освітнього середовища ЗВО розуміється нами як здатність особистості відповідати вимогам і нормам навчального закладу, як здатність розвиватися, реалізовувати свої здібності й потреби, не вступаючи з цим середовищем у суперечності.

Аналіз наукових досліджень із проблеми адаптації в освітній галузі (Г. Алексєєва, І. Бойко, Л. Волошина, С. Гура, О. Мороз, В. Цибулько та ін.) дав змогу довести, що в педагогіці однозначні за тлумаченяям поняття «навчальна адаптація» й «професійна адаптація». Натомість недостатньо чітко визначено категорію адаптації особистості до освітнього середовища закладу вищої освіти в процесі її фахової підготовки. Тому в контексті наукових інтерпретацій базових понять «професійна адаптація», «соціально-професійна адаптація», «готовність до професійної адаптації», «адаптаційна готовність майбутнього фахівця до професійної діяльності» узагальнено, що феномен «адаптація до професійної діяльності» - це складний процес поетапного входження особистості в майбутню професію, який започатковується ще в умовах освітнього середовища закладу вищої освіти. Він поліфункціональний і $є$ необхідною умовою та засобом ідентифікації людини 3 фаховою діяльністю, оптимізації взаємодії з професійним середовищем - необхідних складників ії професійного становлення й розвитку. Водночас уточнено: сутність досліджуваного явища полягає в тому, що це циклічний процес змін у психіці студента, спрямований на його пристосування до реальних умов професійної діяльності.

Ключові напрямки діяльності педагога, які б сприяли створенню умов для успішної самореалізації та адаптації студентів у суспільному житті, розвивали навички ефективно керувати своїм емоційним станом та формували їхнє активне, позитивне ставлення до нового освітнього середовища, на нашу думку, полягають у визначенні та реалізації конкретних організаційно-педагогічних умов, які, слідом за Н. Бєляєвою та О. Ждановою-Неділько, диференціюємо на середовищні, стимулювально-діяльнісні та превентивні (Бєляєва \& Жданова-Неділько, 2016, с. 17).

1. Середовищні умови протрактуємо як забезпечення сприятливих умов і можливостей соціального й освітнього середовища для оптимального розвитку й адаптації студентів першого й другого курсів й передбачають:

- організацію освітнього процесу з вираженою орієнтацією на обрану професію як цінність;

- інтеграцію освітніх технологій адаптації особистості студента до професійної діяльності;

- створення емоційно комфортного клімату у закладі вищої освіти;

- реалізацію стратегії співробітництва суб'єктів навчально-виховного процесу в умовах освітнього середовища закладу вищої освіти.

2. Стимулювально-діяльнісні умови полягають у стимулюванні розвитку й адаптації через підтримку студента:

- забезпечення індивідуального супроводу студентів відповідно до індивідуальної специфіки та надання їм необхідної корекційної, адаптаційної, соціально-педагогічної допомоги;

- залучення студентів до участі в позааудиторних виховних, розвивальних та організаційно-методичних заходах із метою створення умов для їхньої самореалізації та самоствердження в нових умовах.

3. Превентивні умови вбачаємо в комплексі заходів, що передбачають профілактику дезадаптаційних процесів у студентів першого й другого курсів й спрямовані на:

- лобіювання інтересів студентів із питань поселення в гуртожитку, забезпечення навчальними посібниками, підручниками, іншим навчальним приладдям;

- надання студентам, особливо іногороднім, соціально-педагогічної допомоги зі встановлення нових соціальних зв'язків у навчальному закладі і за його межами, включення їх до нових спільнот різного спрямування (студентське наукове товариство, волонтерські групи, колективи художньої самодіяльності тощо), які б не лише компенсували комунікативні втрати, неминучі при переході від шкільного навчання до навчання в ЗВО, а й формували навички сходження до нового рівня стосунків у соціумі.

Висновки. У цілому зміст окреслених напрямів має забезпечувати успішну адаптацію студентів молодших курсів до освітнього середовища закладу вищої освіти й зосереджений на формуванні позитивної мотивації студентів до особистісно-професійного становлення у новому освітньому середовищі в умовах закладу вищої освіти.

Реалізація указаних організаційно-педагогічних умов, на нашу думку, передбачає методично обгрунтовану організацію навчально-виховного процесу для зазначеної категорії студентів - забезпечення толерантної, особистісно орієнтованої взаємодії викладачів зі студентами; організацію різносторонньої культурно-дозвіллєвої діяльності студентів із метою оптимізації їхнього міжособистісного спілкування; створення умов для їхньої творчої реалізації та особистісного самоствердження; активного залучення до громадського життя групи, факультету, осередків студентського самоврядування.

Подальші наукові пошуки та практичну діяльність за досліджуваним напрямком вбачаємо у детальній розробці та реалізації організаційно-методичних форм і прийомів педагогічної діяльності, необхідних для забезпечення успішної адаптації студентів молодших курсів. 


\section{Список використаних джерел}

Бєляєва, Н., Жданова-Неділько, О. (2016). Організаційно-педагогічні умови адаптації внутрішньо переміщених студентів до університетського середовища. Витоки педагогічної майстерності, 17, 29-34.

Братко, М. В. (2015). Освітнє середовище вищого навчального закладу: функціональний аспект. Педагогічний процес: теорія і практика, 1-2 (46-47), 11-17.

Левківська, Г. П., Сорочинська, В. Є., Штифорук, В. С. (2001). Адаптаиія периокурсників в умовах вищого закладу освіти: [навч. посібник]. Київ.

Ячменьова, В. М., Османова, 3. О. (2010). Сутність понять «адаптація» та «адаптивність». Взято 3 http://ena.lp.edu.ua:8080/bitstream/ntb/18798/1/72-346-353.pdf (дата звернення 12.06. 2020 p.)

\section{References}

Bieliaieva, N., Zhdanova-Nedilko, O. (2016). Orhanizatsiino-pedahohichni umovy adaptatsii vnutrishno peremishchenykh studentiv do universytetskoho seredovyshcha [Organizational and pedagogical conditions of adaptation of internally displaced students to the university environment]. Vytoky pedahohichnoi maisternosti [The origins of pedagogical skills], 17, 29-34 [in Ukrainian].

Bratko, M. V. (2015). Osvitnie seredovyshche vyshchoho navchalnoho zakladu: funktsionalnyi aspect [Educational environment of higher education institution: functional aspect]. Pedahohichnyi protses: teoriia i praktyka [Pedagogical process: theory and practice], 1-2 (46-47), 11-17 [in Ukrainian].

Levkivska, H. P., Sorochynska, V. Ye., \& Shtyforuk, V. S. (2001). Adaptatsiia pershokursnykiv v umovakh vyshchoho zakladu osvity [Adaptation of freshmen in a higher education institution]: [navch. posibnyk]. Kyiv [in Ukrainian].

Yachmenova, V. M., \& Osmanova, Z. O. (2010). Sutnist poniat "adaptatsiia” ta "adaptyvnist” [The essence of the concepts of "adaptation" and "adaptability"]. Retrieved from http://ena.lp.edu.ua:8080/bitstream/ntb/18798/1/72-346-353.pdf [in Ukrainian].

\section{SHARA S.}

Higher Educational Establishment "Poltava University of Economics and Trade”, Ukraine

\section{CONDITIONS OF ADAPTATION OF JUNIOR STUDENTS TO THE EDUCATIONAL ENVIRONMENT OF ZVO IN} THE PROCESS OF PROFESSIONAL TRAINING

The concept of "adaptation" and related concepts and concepts are analyzed. The essence of the concept "adaptation of junior students to the educational environment of higher education in the process of professional training" is clarified.

The social adaptation of first and second year students to the educational environment of a higher education institution is revealed as the ability of an individual to meet the requirements and norms of the educational institution, as the ability to develop, realize their abilities and needs without conflict with this environment. The phenomenon of "adaptation to professional activity" is described as a complex process of gradual entry of a person into a future profession in the educational environment of a higher education institution. It is multifunctional and is a necessary condition and means of identifying a person with a professional activity, optimizing interaction with the professional environment - the necessary components of his professional development and development. At the same time, it is clarified that the essence of the studied phenomenon is that it is a cyclical process of changes in the student's psyche, aimed at his adaptation to the real conditions of professional activity.

The organizational and pedagogical conditions of adaptation of first and second year students to the educational environment of a higher educational institution in the process of professional training (environmental, stimulating-activity, preventive) are determined and substantiated.

Key words: adaptation, students, educational environment, professional training, pedagogical conditions of students' adaptation to the educational environment of a higher education institution in the process of professional training.

Стаття надійшла до редакції 10.08.2020 p. 